\title{
CORRELATION OF SHEEP WELFARE AND BEHAVIOR WITH MEAT QUALITY: A
} REVIEW

MOURA, Sandra Vieira de ${ }^{1}$;

FELIX, Samuel Rodrigues ${ }^{1}$; SILVA, Éverton Fagonde da ${ }^{1}$.

${ }^{1}$ Faculty of Veterinary Medicine, Federal University of Pelotas, Pelotas, Brazil.

\section{ABSTRACT}

S

heep meat is a growing market, especially in developing countries, where the economic growth is more abundant, subsequently increasing the demand. Alongside established markets, these consumers will be requiring better quality of the products, being aware of how the animals are reared, breed and slaughtered. A series of circumstances prior to slaughter can be stressing, and may cause physiological alterations leading to a prejudicial effect on final meat quality. Animals are subject to these circumstances from production unit stunned at the slaughterhouse. This study considers specific characteristics of ovine behavior and meat composition in order to compile a review that addresses both, pre and post, slaughter effects on sheep meat quality. Specifically, we address pre slaughter handling of these animals, aspects of ovine behavior, and its consequences on final meat quality.

Keywords: Humanitarian slaughter. Sheep meat. Animal handling. Glucocorticoids. Stress. 


\section{INTRODUCTION}

The consumption of ovine meat in Brazil is around $700 \mathrm{~g} /$ capta/year, even though it has presented a positive tendency in recent years (FAO, 2009), consumption is still low when compared to $1.4 \mathrm{~kg}$ in Argentina, or $27 \mathrm{~kg}$ in Europe. Lamb production by itself is responsible for a movement of over $\mathrm{R} \$ 360$ million a year in Brazil, while worldwide meat production trends are changing from quantity to quality (BONAGURIO et al., 2003). Sheep meat has high digestibility and low cholesterol rates, setting this product apart from beef and pork, and indicating a clear marketing strategy for the sector. In such a scenario, it is important for a product to stand out and meet the consumers' demands. According to Warriss (1990), people want to eat meat with "ethical quality", that is, animals raised, treated, and slaughtered in systems that promote animal welfare, are sustainable, and environment friendly. The welfare of farm animals has become a worldwide concern (VANHONACKER et al., 2008), especially among Europeans, where it is an ever increasing priority. According to Grandin (2010), administrators, veterinarians, and scientists should have more knowledge regarding the assessment and auditing of animals prior to slaughter. Deiss et al. (2009) suggest that, to reduce animal stress during slaughter it is necessary to understand its cause. However, slaughter procedures are complex and represent several stress risks, some of which are still unknown. Even more understudied are the stress risks in sheep slaughterhouses, making effective welfare promoting, and humanitarian slaughter programs hard to implement for this species. This review will demonstrate the relevance of developing studies associated with behavior and welfare of sheep for slaughter. Furthermore, we will regard the specific characteristics of this species, considering humanitarian slaughter.

\section{ASPECTS OF OVINE BEHAVIOR}

Changes in animal behavior have occurred since they were first domesticated. Sheep are gregarious and, by nature, reluctant to separation or mixture with other animals. When first presented to new situations, they will react with stress and possibly resistance (Grandin, 2000). The population growth has significantly increased the consumption of animals, making the production ever more intensive, substantially altering the available environment for these animals. Thus, physiological and behavioral adaptation on the animals' part must 
be taken into consideration when assessing the production system (LE NEINDRE et al., 1996). Being relatively submissive animals, sheep rarely show signs of pain or suffering, consequently, observing visual indicators is unpractical, and therefore, objective methods must be used to assess the welfare of farm animals (FITZPATRICK et al., 2006). Currently, it is unknown if the increase in the reactivity of sheep during production can predict intense stress reaction during the slaughter process (DEISS et al., 2009). The final $\mathrm{pH}$ is elevated in meat from lambs that are reactive to social separation, and for these animals, the presence of herd mates may reduce stress reactions during the slaughter process. Warriss (1990) reports that sheep seem to be less susceptible to stress than cattle or swine, otherwise, they may have different physiological mechanisms, since muscle contraction was not a prerequisite for the DFD (Dark, Firm and Dry) process in sheep, the opposite of cattle (APPLE et al., 1995).

\section{Ovine stress and welfare}

The welfare of production animals is determined by the production system and animal handling practices imposed by the farmers, which, in turn, are determined by market requirements (MOLENTO, 2005). Oliveira et al. (2008) suggest that the modern consumer wants to know the "history" of the products, such as how the animals were raised, fed, transported, and slaughtered. Traceability programs can be designed to encompass some, most, or all of the life-cycle, from the animal's birth to consumption (SMITH et al., 2005), and are, or should be, thoroughly implemented in developing countries in the next few years, to account for foreign markets. Stress inducing factors may have a physical origin, such as food deprivation, fatigue or adverse temperatures, but they can also have a psychological origin, such as a disturbance in the social group, human presence or exposure to new environments (TERLOUW et al., 2008). To provide a condition of welfare, it is necessary to recognize the situations that trigger adverse reactions in the animal. Distress describes the situation in which sheep are susceptible to suffering and demonstrate abnormal behavior (EWBANK, 1985). Any agent that threatens the animal's wellbeing can lead to distress. Acute infections and environmental changes are potential health threats and can lead sheep to distress (GOUGOULIS et al., 2010). In stressful situations animals will present tachycardia and blood 
redistribution, from the viscera to the skeletal muscles and brain, with behavioral response becoming evident, such as: alert state, immobilization, aggression and escape behavior (FERGUSON; WARNER, 2008). To assess the animals' wellbeing during handling and transport, behavioral and physiological measurements must be considered. Physiological measurements used thus far are autonomic responses, such as heart frequency and hormone levels, usually corticosteroids (KORTE, 2001). Therefore, it is important to highlight those changes in the animals' physiological or behavioral state may indicate that the welfare has been disturbed, and compromise the downstream production chain, depreciating the final product quality (MOLENTO, 2005).

\section{Stress indicators}

Most stress alterations involve the secretion of glucocorticoids and an increased activity of the sympathetic nervous system (SNS). The synchronized control of the hypothalamus, hormones that increase ACTH and catecholamine levels, results in biochemical and physiological manifestations of stress (NOCKELS, 1990). The role played by the supra-renal cortex is the production of gluco and mineralocorticoids, in which cortisol and aldosterone are particularly important in stress. The glucocorticoids, together with the catecholamines, trigger metabolic alterations in order to mobilize and provide energy to the organism through lipolysis, glycogenolysis, and protein degradation. Stress provokes an increase in cortisol levels in the blood, which is associated with hypophysis and adrenal stimulation. The liberation of cortisol by the adrenal cortex is associated with stress stimuli, and has a significantly negative impact on animal performance, immunity, and meat quality (FELL et al., 1999; KING et al., 2006; LACOURT; TARRANT, 1985). Several studies (JARVIS et al. 1996; KRAWCZEL et al., 2007) have found elevated cortisol levels in animals that suffered inadequate grouping and transportation. Stress related hormones can alter metabolic functions in fatty and liver tissues. The hypothalamus-pituitary-adrenal axis (HPA) is one of the endocrinal pathways that promotes lipolysis, increasing the levels of free fatty acids (FFA) in the blood, as well as indirectly causing hyperglycemia. Thus, high blood levels of FFA and glucose are considered trustworthy markers to assess individual responses to different types of stress. The identification of these markers may determine stress levels suffered by 
an animal during the pre-slaughter procedures, allowing the assessment of the physiological and metabolic condition of these animals, and predicting possible alterations in meat quality.

\section{Pre-Slaughter}

Many are the factors that influence pre-slaughter comfort, such as: transportation, fast, and environment. The animals are exposed to the wanderings of humans and other animals that are strange to them, food and water deprivation, social alterations, all of which may disturb the animals physiology (FERGUSON; WARNER, 2008). Studies by Miranda de-la Lama et al. (2010) suggest that the logistic chain, pre-slaughter, is a source of stress for lambs, affecting their physiological state, even under good commercial conditions. According to Grandin (1997), the reunion of animals, the chosen handling methodology, and the new environmental conditions are all causes of psychological stress, while extreme temperatures, hunger, fatigue, and injuries are the main causes of physical stress. Other aspects that require attention include the installations and equipment used (pens at the production, piers, trucks, rattles, pens at the slaughter house, and stunning room), as well as the breed (in terms of reactivity). An assessment by the same authors identified the following problems in pre-slaughter handling that resulted in increasing amount of hematomas in the carcasses: (1) direct aggression; (2) high social density in pens and pier before transport; (3) inadequate installations; (4) inadequate transport; (5) agitated animals as a result of breed reactivity and aggressive handling. Vocalization when conducing the animals or during stunning, has a high correlation with adverse events. Falls and slips are indicative of deficient installations and/or bad handling. Good installations should allow no more than $1 \%$ and $3 \%$ falls and slips, respectively (GRANDIN, 2000).

\section{Transport}

The transport is associated with a change in both physical and social environments. The animals are usually transported in heavy vehicles, where they may suffer injuries and extreme climatic conditions (such as extreme temperatures and rain) (TERLOUW et al., 2008). High density keeps low the transportation cost, however this must be balanced with the animals' welfare. Although some aspects of ovine behavior during transport and housing 
have been described (COCKRAM et al., 2004; JARVIS et al., 1996; MIRANDA-DE LA LAMA et al., 2010), no study has described the effects of pre shipment fasting. In countries such as Australia, sheep and cattle for slaughter must not travel more than ten hours (FERGUSON; WARNER, 2008). Osório et al. (1991) demonstrated that the distances of travel between of 100 to $300 \mathrm{~km}$ influence, in a direct manner, weight loss in mutton (3.81\% to $7.87 \%$ ), sheep (2.29\% to $10.01 \%)$, and lamb $(2.24 \%$ to $9.45 \%)$. Acceptable density patterns for transportation depend on the weight and physiological state of the animals in question. Therefore, trips of three to four hours should have animals grouped by weight, with 0.2 to $0.5 \mathrm{~m}^{2}$ per sheep (TERLOUW et al., 2008). Studies with lambs on the effect of fasting or transport and fasting, have been mostly unable to demonstrate that transport itself is a significant stress factor (KNOWLES, 1999; WARRISS, 1990), while others claim that transport aggravates the weight loss due to fasting (HORTON et al., 1996; THOMPSON et al., 1987). Transport is not only a possible stress event, but also a point of concern for the European commission (SCAHAW, 2002). Road transporting of live sheep follows the same principles set for cattle. The transporting vehicle must have safe and strong, high laterals to prevent the animals from jumping or falling during movement. Also, the floor must be covered with a slip safe surface (GRANDIN, 2000).

\section{Stunning}

Adequate stunning methods are indispensable to guarantee the success of the humanitarian slaughter. At this stage, the most important points are adequate functioning equipment and well trained personnel. Stunning through captive bolt pistols induce deep, irreversible concussions. Generally, five criteria are used to assess the efficiency of the stunning process: immediate collapse of the animal, no need for a second shot, absent corneal reflex, fixed look, and abnormal breathing (GREGORY; SHAW, 2000). Stunning animals prior to slaughter is a legal requirement in most countries. The 1993 93/119/CE council directive of the European Union, as well as the technical regulation for the stunning and humanitarian slaughter of animals (BRASIL, 2000), require that all stunned animals stay in this state until total loss of brain functions due to exsanguination. Therefore, it is essential that efficient stunning methods be used always. In the meat industry, effective stunning also influences 
other factors such as meat quality, haemorrhage and fracture occurrence. However, there is still a lack of information regarding ovine meat quality and the effects of stunning methods (VELARDE et al, 2003). According to Blackmore and Petersen (1981) in practical terms, electric methods seem to be the most cost effective for the stunning of sheep. However, this method usually leads to convulsions, which may increase post mortem glycolysis rates due to high muscle activity, and high catecholamine levels in the blood. For effective stunning, not only is the position of the shot important, but the pistol's angle in relation to the animal's skull, allowing the dart or impact force to hit the brain structures responsible for consciousness: the cerebral cortex, encephalic stem, and the cerebellum (FINNIE, 1993). Summary, stunning must induce a state of unconsciousness that lasts until the end of the exsanguination, without unnecessary suffering and promoting the most complete blood loss possible.

\section{Exsanguination}

Exsanguination is carried out by the opening of the large blood vessels in the dewlap region, cutting the anterior aorta, anterior vena cava, carotid arteries, and jugular veins, no more than one minute after stunning (BRASIL, 2000). An efficient exsanguination, which produces meat with an adequate conservation capacity, should remove at least $60 \%$ of the total blood volume, with $10 \%$ staying in the muscles and the rest in the viscera (HEDRICK et al., 1994). In order to obtain quality meat, the maximum amount of blood must be lost during exsanguination. Badly bled carcasses have an unpleasant aspect, being ideal for bacterial growth. Blood has a high pH (7.35 to 7.45) and high protein content, thus making badly bled meat hard to preserve (ROÇA et al., 2001). During exsanguination, healthy and rested animals lose around half of their blood volume, while those that are stressed or otherwise organically altered present a deficient exsanguination. Exsanguination is the final stage in the humanitarian slaughter. At least three minutes are required after the bleeding before the skinning can begin.

\section{Meat quality}

Meat quality is a combination of flavor, juiciness, texture, softness, and appearance, constituents that influence product acceptance (MADRUGA, 2000). Welfare problems during 
transport and pre-slaughter handling in farm animals may have a negative influence on carcass and meat quality, and therefore cause economic losses. Sensorial quality of sheep meat can be considered an integration of factors that include production (zootechnical factors), processing (ante and post mortem handling), added value, and preparation method (RUSSELL et al., 2005). Similar to carcass characteristics, quality directly affects the consumption of sheep meat. Meat quality is assessed as much for its nutritional value as for its sensorial and organoleptic characteristics. Certain compounds that are present in small amounts can have a marked influence, such as: myoglobin for color, collagen for tenderness, and volatile substances for aroma. Therefore, several aspects must be taken into consideration when assessing the quality of sheep meat. Water retention capacity, $\mathrm{pH}$, sensorial aspects, fat content, fatty acid composition, collagen percentage, and intramuscular fat percentage are among the most important factors (SILVA et al., 2008). In general, an increase in physiological stress or physical activity in farm animals during transportation and pre-slaughter handling leads to depletion of muscle glycogen reserves before slaughter, which may result in a higher ultimate meat $\mathrm{pH}$, greater water holding capacity, darker meat color, and tougher meat (GREGORY; SHAW, 2000). In contrast, some studies suggest handling of sheep pre-slaughter has less effect on meat quality than found in other species, such as pig (BRAZAL; BOCCARD, 1977). However, Pearson et al. (1977) noted that electrical stunning of lambs causes the secretion of noradrenaline and adrenaline into the bloodstream, resulting in levels, respectively, 20 and 14 times higher than in nonstunned lambs. Several factors of the production process, before and after slaughter, influence the final quality of the product. According to Bressan et al. (2001), the consumer market is very demanding regarding the physical quality of meat. Thus, knowing these factors for the different age and weight classes destined for slaughter is essential. To comply with the modern consumer requirements, the production chain must be adapted in order to obtain products with higher nutritional value, sanity, and greater organoleptic qualities. Attributes related with the acceptance of the final product include: fatty acid concentration, $\mathrm{pH}$, color, loss of weight after cooking, water retention, and tenderness (SILVA et al., 2008), factors that negatively alter these parameters have a detrimental in the consumers view. Stress is foremost among the ante mortem factors that influences the final product quality. 
Also notable are breed, age, and sex. These pre-slaughter influences mostly affect the final texture, color, and water retention capacity. Post-slaughter factors influences mostly tenderness, color, aroma, and functional characteristics (such as water retention and emulsification). All these factors, pre and post-slaughter are manageable in order to obtain meat of better quality. According to Devine et al. (2006), aspects related to the welfare and pre-slaughter handling such as those previously mentioned, as well as the resting period after transportation, have a great influence in the final product quality.

\section{CONCLUSION}

The welfare and humanitarian slaughter of sheep is fundamental to achieve the desired levels of meat quality. The extent to which long term or pre-slaughter stress negatively influences meat quality is still unknown, mostly due to a lack of specific studies. Thus, further research in the area is essential to support the development of practices and technologies that will optimize procedures and boost the sector's growth, especially in developing countries, where demanding market are growing rapidly.

\section{CORRELAÇÃO DO COMPORTAMENTO E BEM-ESTAR COM A QUALIDADE DA CARNE OVINA: UMA REVISÃO}

\section{RESUMO}

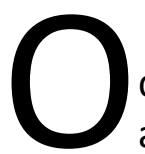

mercado da carne ovina apresenta-se em ascensão, especialmente nos países em desenvolvimento, onde ocorre o crescimento econômico dos consumidores e o aumento da demanda. Em comparação aos mercados já estabelecidos, esses consumidores irão pressionar por uma melhor qualidade dos produtos, na criação, na manutenção e no abate humanitário desses animais. Uma série de circunstâncias pré-abate são estressantes para os animais e podem causar alterações fisiológicas que conduzem a um efeito prejudicial na qualidade final da carne. Animais são submetidos a essas circunstâncias desde a unidade de produção até o abatedouro. Este estudo considera as características específicas do comportamento dos ovinos e a sua composição da carne, a fim de compilar uma revisão que aborda tanto os efeitos do pré e pós-abate sobre a qualidade da carne ovina. Especificamente, foi abordado o manejo pré-abate desses animais, aspectos do comportamento dos ovinos e suas consequências na qualidade final da carne.

Palavras-chave: Abate Humanitário. Carne Ovina. Estresse. Glicocorticoides. Manejo. 


\section{CORRELACIÓN ENTRE EL COMPORTAMIENTO Y EL BIENESTAR CON CALIDAD DE LA CARNE OVINA: UNA REVISIÓN}

\section{RESUMEN}

E I mercado de la carne ovina está en crecimiento, especialmente en los países en desarrollo, donde ocurre el crecimiento económico de los consumidores y el aumento de la demanda. En comparación con los mercados establecidos, estos consumidores irán presionando para productos de mejor calidad, en la crianza, mantenimiento y en la faena humanitaria de esos animales. Una serie de circunstancias anteriores al sacrificio serán estresantes para los animales y pueden producir alteraciones fisiológicas que conducen a un efecto perjudicial sobre la calidad de la carne final. Los animales son sometidos a estas circunstancias desde la unidad de producción hasta el matadero. Este estudio considera las características específicas de comportamiento ovino y de la composición de la carne con el fin de elaborar una revisión que aborda tanto los efectos pre y post sacrificio sobre la calidad de carne del ovino. En concreto, fue abordado el manejo pre-faena de esos animales, aspectos del comportamiento del ovino, y sus consecuencias sobre la calidad final de la carne.

Palabras clave: Faena humanitaria. Carne ovina. Estrés. Glucocorticoides. Manejo de los animales.

\section{REFERENCES}

APPLE, J. K.; DIKEMAN, M. E.; MINTON, J. E.; MCMURPHY, R. M.; FEDDE, M. R.; LEIGHT, D. E.; UNRUH, J. A. Effects of restrain and isolation stress and epidural blockade on endocrine and blood metabolite status, muscle glycogen metabolism, and incidence of dark-cutting longissimus muscle of Sheep. Journal of Animal Science, v. 73, p. 2295-2307, 1995.

BLACKMORE, D. K.; PETERSEN, G. V. Stunning and slaughter of sheep and calves in New Zealand. New Zealand Veterinary Journal, v. 29, p. 99-102, 1981.

BONAGURIO, S.; PÉREZ, J. R. O.; GARCIA, I. F. F.; BRESSAN, M. C.; LEMOS, A. L. S. C. Qualidade da carne de cordeiros Santa Inês puros e mestiços com Texel abatidos com diferentes pesos. Revista Brasileira de Zootecnia, v. 32, p. 1981-1991. 2003.

BRASIL. Ministério da Agricultura. Instrução Normativa no. 3, de 17 de janeiro de 2000. Regulamento técnico de métodos de insensibilização para o abate humanitário de animais de açougue. S. D. A./M. A. A. Diário Oficial da União, Brasília, p. 14-16.

BRAZAL, T.; BOCCARD, R. Efectos de dos tratamientos ante mortem sobre la calidad de la canal y de la carne de cordero. Produccion Animal, v. 8, p. 97-125, 1977. 
BRESSAN, M. C.; PRADO, O. V.; PÉREZ, J. R. O.; LEMOS, A. L. S. C.; BONAGURIO, S. Efeito do peso ao Abate de cordeiros Santa Inês e Bergamácia sobre as características Físico-químicas da carne. Ciência e Tecnologia de Alimentos, v. 21, p. 293-303, 2001.

CARTER, L.; GALLO, C. Effect of long distance transport by road and sea crossing on ferry on live weight losses and carcass characteristics in lambs. Archivos de Medicina Veterinaria, v. 40, p. 259-266, 2008.

COCKRAM, M. S.; BAXTER, E. M.; SMITH, L. A.; BELL, S.; HOWARD, C. M.; PRESCOTT, R. J.; MITCHELL, M. A. Effect of driver behaviour, driving events and road type on the stability and resting behaviour of sheep in transit. Animal Science, v. 79, p. 165-176, 2004.

DEISS, V.; TEMPLE, D.; LIGOUT, S.; RACINE, C.; BOUIX, J.; TERLOUW, C.; BOISSY, A. Can emotional reactivity predict stress responses at slaughter in sheep? Applied Animal Behaviour Science, v. 119, p. 193-202, 2009.

DEVINE, C. E.; LOWE, T. E.; WELLS, R. W.; EDWARDS, N. J.; EDWARDS, J. E.; STARBUCK, T. J.; SPECK, P. A. Pre-Slaughter stress arising from handling and its interactions with electrical stimulation on tenderness of lambs. Meat science, v. 73, p. 304-312, 2006.

EWBANK, R. Behavioral responses to stress in farm animals. In: Animal Stress (ed. GP Moberg). American Physiological Society, Bethesda, p. 71-79, 1985.

FAO. FOOD AND AGRICULTURE ORGANIZATION OF THE UNITED NATIONS. Faostat, statistical databases, 2009. Available in: <www.fao.org>.

FELL, L. R.; COLDITZ, I. G.; WALKER, K. H.; WATSON, D. L. Associations between temperament, performance and immune function in cattle entering a commercial feedlot. Australian Journal of Experimental Agriculture, v. 39, p. 795-802, 1999.

FERGUSON, D. M.; WARNER, R. D. Have we underestimated the impact of pre-slaughter stress on meat quality in ruminants? Meat Science, v. 80, p. 12-19, 2008.

FINNIE, J. W. Brain damage caused by a captive bolt pistol. Journal of Comparative Pathology, v. 3, p. 253-258, 1993.

FITZPATRICK, J.; SCOTT, M.; NOLAN, A. Assessment of pain and welfare in sheep. Small Ruminant Research, v. 62, p. 55-61, 2006.

GOUGOULIS, D. A.; KYRIAZAKIS, I.; FTHENAKIS, G. C. Diagnostic significance of behaviour changes of sheep: A selected review. Small Ruminant Research, v. 92, p. 52-56, 2010.

GRANDIN, T. Assessment of stress during handling and transport. Journal of Animal Science, v. 75, p. 249-257, 1997. 
GRANDIN, T. Livestock Handling and Transport. CABI Publishing, Wasllingford, Oxon (Reino Unido). 2000.

GRANDIN, T. Auditing animal welfare at slaughter plants. Meat Science, v. 86, p. 56-65, 2010.

GREGORY, N. G.; SHAW, F. D. Penetrating captive bolt stunning and exsanguination of cattle in abattoirs. Journal of Applied Animal Welfare Science, v. 3, p. 215-230, 2000.

HEDRICK, H. B.; ABERLE, E. D.; FORREST, J. C.; JUDGE, M. D.; MERKEL, R. A. Principles of meat science. Dubuque: Kendal/Hunt Publ. Co. 1994.

HORTON, G. M. J.; BALDWIN, J. A.; EMANUELE, S. M.; WOHLT, J. E.; MCDOWELL, L. R. Performance and blood chemistry in lambs following fasting and transport. Animal Science, v. 62, p. 49-56, 1996.

JARVIS, A. M.; COCKRAM, M. S.; MCGILP, I. M. Bruising and biochemical measures of stress, dehydration and injury determined at slaughter in sheep transported from farms or markets. British Veterinary Journal, v. 152, p. 719-722, 1996.

KING, D. A.; SCHUEHLE, T. H.; PFEIFFER, C. E.; RANDEL, R. D.; WELSH, J. R.; OLIPHINT, R. A.; BAIRD, B. E.; CURLEY, J. R. K. O.; VANN, R. C.; HALE, D. S.; SAVELL, J. W. Influence of animal temperament and stress responsiveness on the carcass quality and beef tenderness of feedlot cattle. Meat Science, v. 74, p. 546-556, 2006.

KNOWLES, T. G. A review of the road transport of cattle. Veterinary Record, v. 144, p. 197201, 1999.

KORTE, S. M. Corticosteroids in relation to fear, anxiety and psychopathology. Neuroscience and Biobehavioral Reviews, v. 25, p. 117-142, 2001.

KRAWCZEL, P. D.; FRIEND, T.; CALDWELL, D. J.; ARCHER, G.; AMEISS, K. Effects of continuous versus intermittent transport on plasma constituents and antibody response of lambs.

Journal of Animal Science, v. 85, p. 468-476, 2007.

LACOURT, A.; TARRANT, P. V. Glycogen depletion patterns in myofibres of cattle during stress. Meat Science, v. 15, p. 85-100, 1985.

LE NEINDRE, P.; BOIVIN, X.; BOISSY, A. Handling of extensively kept animals. Applied Animal Behaviour Science, v. 49, p. 73-81, 1996.

MADRUGA, M. S. Castrations and slaughter age effects on panel assessment and aroma compounds of the "mestiço" goats meat. Meat Science, v. 56, p. 117-125, 2000. 
MIRANDA-DE LA LAMA, G. C.; RIVERO, L.; CHACÓN, G.; GARCIA-BELENGUER, S.; VILLARROEL, M.; MARIA, G. A. Effect of the pre-slaughter logistic chain on some indicators of welfare in lambs. Livestock Science, v. 128, p. 52-59, 2010.

MOLENTO, C. F. M. Bem-estar e produção animal: aspectos econômicos-revisão. Archives of Veterinary Science, v. 10, p. 1-11, 2005.

NOCKELS, C. F. Mineral alterations associated with stress, trauma, and infection and the effect on immunity. Cont Education Practices Veterinarian, v. 12, p. 1133-1139, 1990.

OLIVEIRA, C. B.; BORTOL, E. C.; BARCELLOS, J. O. J. Diferenciação por qualidade da carne bovina: a ótica do bem-estar animal. Ciência Rural, v. 38, p. 2092-2096, 2008.

OSÓRIO, J. C. S.; SAÑUDO, C.; SIERRA, I. Perdidas por transporte en ovinos. Revista de la Sociedad Española de Ovinotecnia y Caprinotecnia, v. 16, p. 480-486, 1991.

PEARSON, A. J.; KILGOUR, R.; DE LANGEN, H.; PAYNE, E. Hormonal responses of lambs to trucking, handling and electrical stunning. Proceeding of New Zealand Society. Animal Production, v. 37, p. 243-248, 1977.

ROÇA, R. O.; PADOVANI, C. R.; FILIPI, M. C.; SCHWACH, E.; UEMI, A.; SHINKAI, R. T.; BIONDI, G. F. Efeitos dos Métodos de Abate de Bovinos na eficiência da Sangria. Ciência e Tecnologia de Alimentos, v. 21, p. 244-248, 2001.

RUSSELL, B. C.; MCALISTER, G.; ROSS, I. S.; PETHICK, D. W. Lamb and sheep meat eating quality - industry and scientific issues and the need for integrated research. Australian Journal of Experimental Agriculture, v. 45, p. 465-467, 2005.

SCAHAW, E. C. The welfare of animals during transport (details for horses, pigs, sheep \& cattle). Report of the Scientific Committee on Animal Health and Animal Welfare. Brussels, European Commission. 2002.

SILVA, N. V.; SILVA, J. H. V.; COELHO, M. S.; OLIVEIRA, E. R. A.; ARAÚJO, J. A.; AMÂNCIO, A. L. L. Características de Carcaça e Carne Ovina: Uma abordagem das variáveis metodológicas e fatores de influência. Acta Veterinaria Brasilica, v. 2, p. 103-110, 2008.

SMITH, G. C.; TATUM, J. D.; BELK, K. E.; SCANGA, J. A.; GRANDIN, T.; SOFOS, J. N. Review. Traceability from a US perspective. Meat Science, v. 71, p. 174-193, 2005.

TADICH, N.; GALLO, C.; BRITO, M.; BROOM, D. Effect of weaning and 48 hours transport by road and ferry on some blood indicators of welfare in lambs. Livestock Science, v. 121, p. 132-136, 2009.

TARUMÁN, J.; GALLO, G. Bruising in lamb carcasses and its relationship with transport. Archivos de Medicina Veterinaria, v. 40, p. 275-279, 2008. 
TERLOUW, E. M. C.; ARNOULD, C.; AUPERIN, B.; BERRI, C.; LE BIHAN-DUVAL, E.; DEISS, V.; LEFE, V. R. E. F.; LENSINK, B. J.; MOUNIER, L. Pre-slaughter conditions, animal stress and welfare: current status and possible future research. Animal, v. 2, n. 10, p. 1501-1517, 2008.

THOMPSON, J. M.; O'HALLORAN, W. J.; MCNEILL, D. M. J.; JACKSON-HOPE, N. J.; MAY, T. J. The effect of fasting on live weight and carcass characteristics in lambs. Meat Science, v. 20, p. 293-309, 1987.

VANHONACKER, F.; VERBEKE, W.; VANPOUCKE, E.; TUYTTENS, F. Do citizens and farmers interpret the concept of farm animal welfare differently? Livestock Science, v. 116, p. 126136, 2008.

VELARDE, A.; GISPERT, M.; DIESTRE, A.; MANTECA, X. Effect of electrical stunning on meat and carcass quality in lambs. Meat Science, v. 63, p. 35-38, 2003.

WARRISS, P. D. The handling of cattle pre-slaughter and its effects on carcass meat quality. Applied Animal Behaviour Science, v. 28, p. 171-186, 1990. 